\title{
Why Aren't There More Republican Women in Congress? Gender, Partisanship, and Fundraising Support in the 2010 and 2012 Elections
}

Karin E. Kitchens

Georgetown University

Michele L. Swers

Georgetown University

Since the early 1990s, women have slowly increased their presence in Congress. However, a gap has opened up such that the number of
Democratic women far outpaces the number of Republican women. Indeed, in the 114th Congress, women constituted one-third of the Democratic caucus but less than $10 \%$ of the Republican caucus (Center for the American Woman and Politics 2015). To better understand the electoral environment women candidates face and how challenges vary for Republican and Democratic women, we focus on one of the most critical elements of a viable candidacy: fundraising. Previous studies of the impact of gender on fundraising analyze general election nominees but do not evaluate differences in the experience of all primary candidates. Moreover, past studies do not fully examine differences in sources and levels of financial support across all partisan and gender groups, including Democratic men and women and Republican men

Published by Cambridge University Press 1743-923X/16 \$30.00 for The Women and Politics Research Section of the American Political Science Association.

(C) The Women and Politics Research Section of the American Political Science Association, 2016 doi:10.1017/S1743923X1600009X 
and women. By examining fundraising in primary elections in addition to general elections, we shed light on the impact of partisanship, gender, and candidate experience in this critical winnowing stage when candidates compete to demonstrate their viability to donors and party voters.

Our research provides a comprehensive analysis of the impact of gender and partisanship on candidate fundraising in the 2010 and 2012 elections. We conduct the first in-depth study of all candidates who ran in the primary. Past studies that focus on general election candidates or the primary fundraising experience of these party nominees ignore the large proportion of women candidates who run and lose their primaries. Yet nonincumbent primary candidates are the most likely to experience any potential inequities in fundraising because they do not have an established relationship with the party, political action committees (PACs), and individual donors. Given the small number of Republican women in Congress, most female Republican candidates run as challengers. The 2010 and 2012 elections saw record numbers of Republican women running for office. These two elections represent a wave election year for Republicans in 2010 and a more balanced partisan environment in the 2012 elections, in addition to capturing fundraising in a midterm and a presidential election contest. Our research analyzes fundraising across multiple sources, including individual donations (itemized and unitemized), party support, and PAC contributions, as well as total amounts raised.

We find clear differences in the fundraising experience of male and female Republicans and Democrats. While incumbency, district competitiveness, and candidate quality drive fundraising success in the general election, we find that women, particularly Democratic women, are more successful fundraisers than their male counterparts in the primary. However, Republican women do not enjoy greater fundraising success compared with similarly situated male candidates, and in some circumstances, being a Republican woman can be an impediment to raising money in the primary.

\section{GENDER AND CAMPAIGN FINANCE}

The ability to raise large amounts of money is central to success in the candidate-centered campaigns that characterize U.S. congressional elections (Herrnson 2012; Jacobson 2013b). In 2012, the average House winner spent approximately $\$ 1.57$ million (see http://www.opensecrets.org/ 
bigpicture/elec_stats.php?cycle=2012). The recent rise of super PACs and other organizations focused on independent expenditures only increases the need to raise large sums (Hermson 2012; Jacobson 2013a). Fundraising is a pivotal factor in the candidate emergence stage. Aspiring candidates must see a path to raising money when considering whether to throw their hat in the ring. Given that the networks of donors that contribute to political campaigns are overwhelmingly male dominated (Burns, Schlozman, and Verba 2001; Francia et al. 2003), aspiring female candidates may have more difficulty imagining and assembling a coalition of financial backers. Indeed, surveys regarding political ambition and candidate attitudes indicate that women devote more time and effort to fundraising and that women are more deterred by the costs of a campaign, particularly the need to fundraise (Fulton et al. 2006; Jenkins 2007). Beyond the ambitions of individual aspirants, parties consider fundraising a key test of viability. To earn party backing, candidates must first demonstrate their ability to raise money (La Raja 2013).

Given the centrality of fundraising to candidate success, it is important to examine gender and partisan differences in the fundraising experiences of male and female Republican and Democratic candidates. Previous research finds that male and female candidates raise equivalent sums once we account for seat status and the partisan electoral environment (Burrell 1994, 2014; Fiber and Fox 2005; Green 2003; Hogan 2007). Yet the majority of research on gender and fundraising activities only examines the experience of general election nominees. Some studies focus only on particular types of general election candidates such as open seat races, which provide the best opportunity for electoral success (Fiber and Fox 2005; Green 1998). Therefore, we do not know whether women have more difficulty raising money in the early stages of the campaign. The few studies that examine primary fundraising look only at the records of the winners who become general election nominees (Burrell 1994, 2014; Francia 2001) and/or particular subsets of candidates such as open seat primaries (Burrell 1994, 2014). We cannot assess whether women have more trouble accessing the networks that finance campaigns because there have been no comparisons of the fundraising records of men and women who lose their primary.

By including all candidates who compete in primary elections, we can assess whether women with similar levels of experience have more difficulty demonstrating their viability and attracting donors in the competition to secure the party nomination. The strength of a candidate's fundraising network is particularly important in the primary phase. Because 
all candidates share the same party label and the national parties are reluctant to interfere in primaries, primary elections are particularly candidate-centric (Boatright 2013). Individual candidates must rely on their own persona and narrative to attract donors and endorsements by local party figures and opinion leaders. If women have more difficulty breaking into the networks of activists, politicians, and business leaders that fund campaigns, these difficulties should be more apparent in the primary.

In addition to neglecting fundraising patterns in primary elections, most studies that examine the impact of gender and partisanship include separate controls for party and sex but do not interact these variables in their regression analyses, making it more difficult to delve into the differences across and among Republican and Democratic men and women (see, e.g., Burrell 1994, 2014; Fiber and Fox 2005; Green 1998, 2003). There are important reasons to believe that Republican women may have more difficulty fundraising than Democratic women. The districts that are most likely to elect female candidates are districts that are more urban, liberal, higher income, and more racially diverse. These are increasingly Democratic districts, whereas the strength of the Republican Party is in the southern and rural districts that are distinctly unfriendly to women candidates (Elder 2008, 2012; Palmer and Simon 2012). In her study of party chairs, Sanbonmatsu (2006) finds that state party leaders believe there are certain parts of their states that will not elect a female candidate, which are often the more rural areas.

In addition to running in more female-friendly districts, Democratic women benefit from the evolution of the parties' electoral coalitions. The civil rights and feminist movements shifted the traditional party coalitions and fueled a network of organizations, activists, and donors who prioritize diversity and may be more open to giving money to elect female candidates and expand the representation of women in office (Burrell 2014; Sanbonmatsu 2002; Wolbrecht 2000). Indeed, research on the fundraising activities of women's groups highlight the importance of female donor networks, particularly EMILY's List, which only donates to pro-choice female Democrats, as an important source of campaign funding for women (Burrell 1994, 2014; Cooperman 2013; Crespin and Dietz 2010; Elder 2014; Francia 2001). Crespin and Dietz (2010) find that Democratic female general election candidates raised more individual donations than male Democrats, but there were no differences in the amount of individual donations raised by Republican men and women. Reinforcing the importance of women's groups, only the Democratic women who were part of a female donor network raised 
more individual contributions than their male Democratic counterparts. Similarly, in a study of women general election candidates, Francia (2001) demonstrates that the Democratic women who raised the most money from women's PACs also raised more money overall and earned a higher percentage of the vote than Democratic women who did not receive money from these PACs. However, Republican women who raised money from women's groups did not have higher fundraising totals or earn more votes than other Republican women.

Finally, seeming equality in fundraising success may mask underlying differences in the experiences of male and female candidates. Recent research on election outcomes and vote shares indicates that women have to work harder and be more qualified to achieve the same results. Examining primaries, Lawless and Pearson (2008) and Palmer and Simon (2012) find that Democratic and Republican female candidates face more competitive primaries and draw more candidates to the opposition party primary (but see Burrell 2014, who finds no difference in primary competitiveness after accounting for seat status). Thus, women and men may win at equivalent rates, but women face a more competitive process. Other research finds that women candidates, particularly Democrats, need to be more qualified and run in more partisan-friendly districts to achieve the same election rates and vote shares as men (Fulton 2012; Pearson and McGhee 2013).

With regard to fundraising, Herrick (1996) finds that female challengers had to spend more money than male challengers to win the same share of votes, and the disparity was largest for Republican women. Meanwhile, Crespin and Dietz (2010) find that women raise more money in individual donations. However, this success with individual donors is driven by small contributions under $\$ 200$. Therefore, women need to develop a larger network of contributors to raise equivalent funds. Clearly, we need to delve more deeply into partisan and gender differences in candidate fundraising. Our focus on both the primary and the general election stage provides a more nuanced and comprehensive understanding of how gender and partisanship impact candidate fundraising.

\section{A THEORY OF THE IMPACT OF GENDER AND PARTISANSHIP ON FUNDRAISING}

To gain a more thorough understanding of how gender and partisanship affect fundraising, we use data compiled by the Federal Election 
Commission (FEC). Candidates are required to file quarterly reports that contain information about the amount of money donated and the source of the donation. We examine all reports filed with the FEC. For the primary analysis, we include all reports filed up to and including the preprimary reports. The pre-primary report includes all money raised up to 20 days before the election. These reports provide the best estimate of fundraising through the primary election. For general election candidates, we aggregate the money raised in the primary election period and the money raised in all reports up through the post-general report. The reports provide information on the amounts candidates receive from individual donations, which include unitemized donations of less than $\$ 200$ and itemized donations greater than $\$ 200$. We also examine the money candidates raise from PACs and party committees. Finally, we analyze the total contributions candidates raise.

The 2010 elections represent a high point in the number of Republican women running for office. Among the 1,777 primary candidates, there were 130 Republican women and 135 Democratic women running in the primaries. The electoral environment in 2010 was very favorable for Republicans. Ultimately, Republicans won 63 seats in this wave election and took over the majority in the House. In 2012, there was a presidential election and a more status quo electoral environment, with 1,660 candidates running for Congress. The election included the second-largest contingent of female Republican candidates, 107, and 190 Democratic women.

$\mathrm{H}_{1}$ : Gender and partisan differences in fundraising success are more likely to emerge in primaries than in the general election. The strongest differences will be found among the open seat and challenger candidates, who are competing to demonstrate their viability to donors, the party hierarchy, and voters.

We expect to find greater gender differences in the fundraising activities of primary election candidates than general election candidates. The candidates in primary elections represent a wider range of experience and viability. It is in the primary that candidates seek to prove their electability and the parties are more careful about whether they will endorse a candidate and whom they will support (Herrnson 2012; Jacobson 2013b). Because all candidates are running under the same party label, the primary election is more candidate centered, and the characteristics and personal connections of individual candidates are even more important. If there are differences in the levels of access that 
men and women have to the financial networks and party endorsements that support campaigns, these should emerge in the competition for funds among male and female challenger and open seat candidates in the primary.

$\mathrm{H}_{2}$ : Compared with their male copartisans, Democratic women should have greater success in tapping their party's fundraising networks. Republican women will not raise more money than their male copartisans, and gender may create fundraising obstacles for Republican women.

We expect that relative to their male partisan counterparts, Democratic women will be more successful fundraisers than Republican women, enjoying greater access to the networks of donors that support their party's candidates. Recent research on political parties demonstrates that parties are networks of activists and interest groups working to recruit and elect candidates who will be committed to a common party agenda (Bawn et al. 2012). Thus, candidates must create a profile that will attract a partisan donor pool that is particularly focused on the candidate's issue positions. This is especially important for House candidates, who receive a large proportion of their funds from individual contributions, particularly large individual contributions of more than $\$ 200$. Indeed, large individual contributions constitute an even greater proportion of the campaign receipts of challengers and open seat candidates than of incumbents. In 2010, on average, incumbents received $44 \%$ of their contributions from large individual contributions, while challengers collected $50 \%$ and open seat candidates raised $58 \%$ of their receipts from large individual contributions (Herrnson 2012).

The activists who constitute the individual donor pool are motivated by ideology (Barber 2016; Boatright 2013; Francia et al. 2003, 2005; Gimpel, Lee, and Pearson-Merkowitz 2008; Johnson 2010). In the current partisan and polarized electoral environment, Democratic women should benefit from the fact that they are generally more liberal than Democratic men (Frederick 2009; Pearson 2013), and they are perceived to be more liberal by voters (King and Matland 2003; Koch 2000). As a result, Democratic women should attract even more of these liberal Democratic donors than Democratic men.

Furthermore, the importance of the civil rights and feminist movements in shaping the ethos of the modern Democratic Party means that Democratic donors will be more responsive to calls to donate to female candidates. Additionally, party-aligned groups, especially EMILY's List, have spent years building female donor networks to boost the electoral 
fortunes of Democratic women candidates, providing an additional source of funds solely benefiting Democratic women (Burrell 2008, 2010, 2014; Cooperman 2013; Crespin and Dietz 2010; Elder 2014; Francia 2001).

By contrast, Republican women may have more difficulty raising funds in comparison to their male Republican counterparts. While Democratic women are perceived as more liberal, Republican women are assumed to be more moderate than Republican men (King and Matland 2003; Koch 2000). This perception of moderation is likely not helpful in the current polarized environment, in which Republican primary voters and donors are among the most conservative (Abramowitz 2010; Francia et al. 2003, 2005; Johnson 2010). Even though conservative women are more likely to run in the current environment (Thomsen 2015), these Republican women may need to raise and spend more money to prove their conservative credentials.

The need to prove one's conservative credentials is particularly important in the current political environment. Boatright (2013) finds that periods of high electoral competition draw more challengers to party primaries, particularly for the party that benefits from the wave. Thus, since the 2006 midterms, the number of primary challengers has risen; this is particularly true on the Republican side. As a result, Republican women competing in more crowded primaries must demonstrate that they are the most qualified conservative candidate to an individual donor pool that is strongly motivated by ideology. Furthermore, Republican Party culture rejects calls to elect more women, arguing that merit rather than demographic representation should guide candidate recruitment (Burrell 2014; Elder 2014). As a result, unlike Democratic women, Republican women cannot draw on an established female donor network to buoy their campaigns, making their ability to connect with traditional party fundraising sources even more essential.

$\mathrm{H}_{3}$ : Differential levels of female candidate success may stem from partisan and gender differences in fundraising among quality candidates, the most viable candidates among those competing in primary elections.

Finally, we take a closer look at the experience of female quality challengers. Recent research indicates that gender-neutral outcomes mask systematic biases in the electoral environment, such that women have to work harder and be more qualified to achieve the same results (Fulton 2012; Herrick 1996; Pearson and McGhee 2013). As a result, female quality challengers, as measured by having held previous elective office, may work harder and raise more money than similarly situated 
male quality challengers. Alternatively, women may not reap the same benefits from their quality status, finding it harder to break into the donor networks that fund their party's campaigns, and therefore they will raise less money than male quality challengers.

\section{MEASURING FUNDRAISING SUCCESS: THE DATA}

To analyze how fundraising varies across partisan and gender groups at different stages of the electoral process, we utilize ordinary least squares (OLS) regression models in which the dependent variable takes the log of the amount raised in unitemized individual donations under $\$ 200$, large individual donations, PAC money, party contributions, and total contributions in the 2010 and 2012 elections. Because of the skewed nature of campaign contributions and potential outliers, we use the natural log of each contribution type as our dependent variable, adding an offset to account for the zeros. We use robust standard errors clustered on the congressional district to adjust for the correlation within the districts. Our analysis includes all candidates who competed in either the primary or the general election and filed a report with the FEC. The FEC requires candidates who raise a minimum of $\$ 5,000$ to file a report. ${ }^{1}$ Thus, the analysis focuses on candidates who were serious enough about a race that they raised money and did not drop out before the primary or convention that selects the general election nominee. To make sure our models were not sensitive to the exclusion of those who raised little or no money, we also analyzed models that included all candidates who ran. $^{2}$ The results of these

1. To identify candidates, we examine the reports candidates filed with the FEC for the 2010 and 2012 elections and the FEC list of "Official Election Results for the U.S. House of Representatives." For example, the 2010 list of candidates can be found at http://www.fec.gov/pubrec/fe2010/ federalelections2010.shtml.

2. We also exclude candidates who ran unopposed in both the primary and the general election. This includes 20 candidates in 2010 and 4 candidates in 2012. These candidates do not face the same fundraising imperatives that most candidates confront. In the models on primary candidates in 2012, we also drop candidates from Louisiana because the state's primaries were held simultaneously with the general election; therefore, we cannot calculate a value for the number of days from January 1 to the primary. We exclude Michele Bachman (R-MN) from the analysis in both 2010 and 2012. Gearing up for a 2012 presidential campaign, Bachman far out-raised her male and female counterparts across the partisan spectrum. For example, according to the Center for Responsive Politics, in 2012, the average incumbent raised \$1.6 million, while Bachman raised more than $\$ 22$ million. Moreover, most of Bachman's money, more than $90 \%$, came from ideologically like-minded individual donors, while the average incumbent raises approximately $67 \%$ of their funds from individual donations (Herrnson 2012). In the general election models, we exclude candidates who were unopposed in the general election. 
models were largely similar to the models reported here and are not shown. ${ }^{3}$

Table 1 includes more information about the partisanship and gender of the candidates in the sample and the average amount of money they raised. Consistent with previous findings, incumbents raised the most money across elections. Female Republican incumbents raised as much or more money than male Republican incumbents, while female Democratic incumbents raised less money than Democratic male incumbents in 2010 and more than male incumbents across the primary and general election cycles in 2012. The enhanced fundraising for male Democratic incumbents in 2010 may reflect the fact that there were more male incumbents running in endangered seats and more money being directed to those races. Looking at challengers and open seat candidates, Democratic women out-raised Democratic men in both the primary and general election cycles, with the exception of female Democratic challengers running in the 2012 general election.

Among Republicans, the sheer number of male challengers in 2010 is striking. There were 529 male challengers who raised enough money to file an FEC report in 2010 compared to 227 male Republican challengers in 2012. Looking at 2010 male Republican challengers and open seat candidates, on average, both the primary and general election candidates raised more money than their female counterparts. However, in 2012, Republican women running as challengers and open seat candidates in primaries and in the general election raised more than similarly situated men, with the exception of female challengers running in the primary. Because Republican women are most likely to be challengers running in primary elections, it appears that these female candidates had more difficulty raising money than the male Republican primary challengers.

Because we want to understand how the sources and overall amount of fundraising varies across party and gender, we use OLS regression to model candidate fundraising. Our main independent variables of interest in the models are candidate sex (women are coded 1 and men 0 ) and partisanship (Republicans are coded 1 and Democrats 0 ). We include an interaction term for Republican women. To more thoroughly evaluate how the fundraising experience of male and female candidates varies across different types of candidates, we also run separate models by candidate status to examine how gender and partisanship differentially

3. The models are available from the authors upon request. 
Table 1. Average money raised by gender, party, and seat status, 2010 and 2012

\begin{tabular}{|c|c|c|c|c|c|c|}
\hline \multirow[b]{2}{*}{ Primary } & \multicolumn{3}{|c|}{2010} & \multicolumn{3}{|c|}{2012} \\
\hline & Number & Mean & SD & Number & Mean & SD \\
\hline Democrat, challenger, male & 171 & 108,472 & 278,862 & 208 & 176,422 & 306,871 \\
\hline Democrat, open, male & 55 & 279,931 & 375,067 & 87 & 333,552 & 533,466 \\
\hline Democrat, incumbent, male & 181 & $1,061,496$ & 690,700 & 121 & 901,229 & 490,487 \\
\hline Democrat, challenger, female & 42 & 259,313 & 495,664 & 70 & 203,591 & 407,013 \\
\hline Democrat, open, female & 20 & 328,627 & 379,814 & 35 & 418,350 & 509,676 \\
\hline Democrat, incumbent, female & 54 & 940,986 & 598,836 & 46 & 925,456 & 648,315 \\
\hline Republican, challenger, male & 529 & 147,451 & 333,389 & 227 & 109,084 & 214,924 \\
\hline Republican, open, male & 139 & 245,052 & 310,637 & 145 & 202,113 & 308,662 \\
\hline Republican, incumbent, male & 131 & 845,065 & 571,960 & 191 & $1,115,913$ & $1,024,320$ \\
\hline Republican, challenger, female & 74 & 114,661 & 236,104 & 39 & 81,305 & 146,261 \\
\hline Republican, open, female & 23 & 167,273 & 220,351 & 21 & 298,609 & 446,438 \\
\hline Republican, incumbent, female & 14 & 890,413 & 330,587 & 22 & $1,151,628$ & 525,617 \\
\hline General & Number & Mean & $S D$ & Number & Mean & $S D$ \\
\hline Democrat, challenger, male & 92 & 298,962 & 558,162 & 117 & 629,308 & 876,095 \\
\hline Democrat, open, male & 25 & 964,691 & 848,046 & 35 & $1,041,193$ & $1,003,627$ \\
\hline Democrat, incumbent, male & 179 & $1,629,460$ & 872,751 & 109 & $1,418,220$ & 777,884 \\
\hline Democrat, challenger, female & 25 & 601,139 & $1,174,909$ & 49 & 554,440 & $1,025,574$ \\
\hline Democrat, open, female & 9 & $1,031,812$ & 752,626 & 16 & $1,413,128$ & 935,392 \\
\hline Democrat, incumbent, female & 53 & $1,461,390$ & 836,103 & 41 & $1,525,853$ & 982,365 \\
\hline Republican, challenger, male & 190 & 727,167 & 857,631 & 104 & 429,232 & 719,445 \\
\hline Republican, open, male & 34 & $1,280,934$ & 735,818 & 45 & 996,139 & 744,570 \\
\hline Republican, incumbent, male & 118 & $1,370,000$ & $1,011,530$ & 175 & $1,772,245$ & $1,605,367$ \\
\hline Republican, challenger, female & 29 & 564,302 & 607,233 & 18 & 482,122 & 753,249 \\
\hline Republican, open, female & 2 & $1,263,429$ & 327,833 & 6 & $1,338,697$ & 925,381 \\
\hline Republican, incumbent, female & 14 & $1,371,635$ & 456,440 & 19 & $1,749,486$ & 706,322 \\
\hline
\end{tabular}


affect the fundraising activities of incumbents versus challenger and open seat candidates. We combine the 2010 and 2012 dataset and include a dummy variable for the 2012 presidential election to account for differences in the electoral and fundraising environment in a presidential year.

We incorporate additional independent variables that are known to impact candidate fundraising. Because incumbents have such a large fundraising advantage, we include a variable for incumbency. Among incumbents, a member's position in the institution can yield important fundraising advantages. Therefore, we include variables for party leaders, committee chairs and ranking members, and members with seats on the prestige committees, including Appropriations, Ways and Means, and Rules. ${ }^{4}$ We also account for open seat candidates because these races are generally more competitive and attract more donations. Challengers are the excluded category.

To capture the competitiveness of individual races, a measure for competitive district includes districts that were rated as toss-up or leaning to one party by the Cook Political Report. ${ }^{5}$ We measure the competitiveness of the primary by including variables for candidates who ran unopposed and candidates who faced only one opponent in the primary election. Candidates who ran against two or more opponents in the primary are the excluded category. ${ }^{6}$ The district vote for President Barack Obama indicates district partisanship and provides a measure of how safe the district was for the candidate's party. We include an interaction between the Obama vote and the Republican Party to account for the fact that President Obama's level of support in the district will have differential effects for Democratic and Republican candidates.

4. The party leaders include the Speaker of the House; majority/minority leader; majority/minority whip; Democratic Caucus chair and vice chair; Republican Conference chair, vice chair, and secretary; Democratic and Republican Campaign Committee chairs; Republican Policy Committee chair; Democratic Steering Committee co-chairs; Democratic senior chief deputy whip; and Republican chief deputy whip. For the 2012 elections, we also include the assistant to the Democratic leader, James Clyburn (D-SC), and the chair of the Democratic National Committee, Debbie Wasserman-Schultz (D-FL).

5. In the general election, the competitive district variable represents the candidates rated as competing in a toss-up race or a race that leans to one party or the other. For the models on primary candidates, we use the variable to identify candidates competing in districts expected to have a competitive general election contest.

6. In the primary election models, we do not exclude candidates who were unopposed because they may be unopposed in the primary but raising significant funds in anticipation of a competitive general election contest. In the general election models, we exclude candidates who are unopposed in the general election and include the dummy variable for candidates who were unopposed in their primary. 
To analyze candidate quality, we identify challenger and open seat candidates who held previous elective office and thus have experience running a campaign, such as state legislators, mayors, or city council members. ${ }^{7}$ We include a variable indicating whether a candidate was running against a quality opponent, which accounts for the fact that the quality of the opposition affects how much money a candidate needs to raise. Because we want to examine whether the fundraising success of quality candidates varies by gender, we include an interaction term that incorporates female quality candidates. This variable allows us to test for gender effects such as whether female quality candidates raise more money than male quality candidates or, alternatively, whether female quality candidates have less access to fundraising networks than similarly situated male candidates. We also include a variable for whether the candidate also ran in the previous election cycle to account for candidates who have run previous campaigns and frequent candidates who are less viable than other competitors. For the primary models, we include a variable that measures the number of days between January 1 of the election year and the date of the primary to account for the fact that candidates with later primaries have more time to raise money.

Finally, because the donors who give the most to campaigns are geographically concentrated in a small number of cities and states (Gimpel, Lee, and Kaminski 2006) and because scholars have found that women are more likely to be elected from specific districts that are more wealthy, racially diverse, and urban, we include additional measures of district characteristics (Palmer and Simon 2012; Pearson and McGhee 2013). These district-level measures from the U.S. census include median household income, the proportion of the population that is white, and the proportion of urban residents.

\section{EVALUATING GENDER AND PARTISAN DIFFERENCES IN FUNDRAISING: ANALYSIS AND RESULTS}

We demonstrate that there are important partisan and gender differences in the sources of funding and the overall fundraising success of Democratic and Republican men and women, especially in the primary. Concentrating solely on the general election, our analysis corroborates

7. We thank Gary Jacobson for providing candidate quality data for 2010 and 2012 general election candidates. We thank Stephen Pettigrew for providing candidate quality data for 2010 primary election candidates. The authors collected 2012 candidate quality data for primary election candidates from America Votes and various Internet sources. 
previous findings that women candidates who win their party's nomination raise just as much money as similarly situated male candidates (Burrell 1994, 2014; Fox and Fiber 2005). Thus, among general election candidates, success in fundraising is largely driven by incumbency status, competitiveness of the election, and candidate quality (see Table 2).

However, even in the general election, there are some differences in the sources of campaign money for male and female candidates. Supporting previous research, female candidates raised more of their campaign money from small individual donations of less than \$200 (Crespin and Dietz 2010; Dabelko and Herrnson 1997; Francia 2001). This result is driven by Democratic women, particularly female Democratic incumbents, who raised significantly more money in unitemized contributions in both the 2010 and 2012 elections. Because we use a log-linear model, we can interpret our coefficients by taking the exponent of the appropriate coefficient or set of coefficients and interpreting it as a percentage change. Thus, a female Democrat incumbent is predicted to raise $98.6 \%$ more in small individual donations than a male Democrat incumbent with the same district characteristics, race competitiveness, and committee membership. ${ }^{8}$ Because individual donors are more ideologically extreme than average voters and small donors are motivated to donate to candidates who share their policy views (Barber 2016; Francia et al. 2003, 2005; Johnson 2010), Democratic women likely benefit from the perception that they are more liberal (Koch 2000). Similarly, these female Democratic candidates are also helped by the integration of women and women's groups into the party base, making activists and donors more responsive to calls to elect women. The strong performance of Democratic women with small donors also aligns with research on women's groups that demonstrates that Democratic but not Republican women benefit from the bundling of individual donations by women's groups, particularly EMILY's List (Crespin and Dietz 2010; Francia 2001).

By contrast, Republican women do not collect more money from small donors than Republican men do. Overall, Republican open seat and challenger candidates have a fundraising advantage over nonincumbent Democrat candidates in small donations in the general election. However, being a Republican woman has no additional statistically

8. The associated $95 \%$ confidence interval is $36.8 \%$ to $188.8 \%$. Because the dependent variable is on the log-scale, small changes on the log-scale can result in large percentage changes. We report the point estimate, but the $95 \%$ confidence intervals for logged variables vary widely. 
Table 2. General election unitemized donations under $\$ 200$ by candidate status and with female quality candidate

\begin{tabular}{|c|c|c|c|c|c|}
\hline Variables & All & $w /$ Fem $Q C$ & No Incum & w/ Fem QC & Incum \\
\hline \multirow[t]{2}{*}{ Female } & $0.562^{* * * ;}$ & $0.467^{*}$ & 0.425 & 0.202 & $0.686^{* * *}$ \\
\hline & $(0.187)$ & $(0.200)$ & $(0.314)$ & $(0.382)$ & $(0.186)$ \\
\hline \multirow[t]{2}{*}{ Republican } & $1.416^{* ; *}$ & $1.425^{*}$ & $2.617^{2}$ & $2.613 * *$ & $-1.492+$ \\
\hline & $(0.509)$ & $(0.508)$ & $(0.785)$ & $(0.785)$ & $(0.772)$ \\
\hline \multirow{2}{*}{ Female * Rep } & -0.791 & $-0.796^{*}$ & -0.324 & -0.297 & $-1.386^{*}$ \\
\hline & $(0.371)$ & $(0.371)$ & $(0.497)$ & $(0.496)$ & $(0.598)$ \\
\hline \multirow[t]{2}{*}{ Incumbent } & $1.056^{* * *}$ & $1.055 \%$ & & & \\
\hline & $(0.166)$ & $(0.166)$ & & & \\
\hline \multirow[t]{2}{*}{ Open } & 0.298 & 0.292 & $0.355+$ & $0.360+$ & \\
\hline & $(0.190)$ & $(0.189)$ & $(0.188)$ & $(0.188)$ & \\
\hline \multirow[t]{2}{*}{ Competitive district } & $1.443^{*}$ & $1.451^{*}$ & $1.633 \%$ & 1.647 的 & $0.794^{* * *}$ \\
\hline & $(0.115)$ & $(0.114)$ & $(0.146)$ & $(0.146)$ & $(0.187)$ \\
\hline \multirow[t]{2}{*}{ Opponent quality can } & $0.245^{*}$ & $0.233^{*}$ & 0.083 & 0.047 & $0.307^{*}$ \\
\hline & $(0.105)$ & $(0.105)$ & $(0.194)$ & $(0.196)$ & $(0.120)$ \\
\hline \multirow[t]{2}{*}{ Nonincumbent quality can } & $0.959 *$ & $0.847^{* * * *}$ & $0.847 * \cdots$ & 0.715 & \\
\hline & $(0.152)$ & $(0.160)$ & $(0.150)$ & $(0.161)$ & \\
\hline \multirow[t]{2}{*}{ Unopposed } & -0.063 & -0.066 & -0.041 & -0.045 & \\
\hline & $(0.134)$ & $(0.134)$ & $(0.218)$ & $(0.219)$ & \\
\hline \multirow[t]{2}{*}{ One competitor } & -0.121 & -0.125 & -0.070 & -0.071 & \\
\hline & $(0.150)$ & $(0.151)$ & $(0.232)$ & $(0.232)$ & \\
\hline \multirow[t]{2}{*}{ Female * Quality } & & $0.557+$ & & 0.670 & \\
\hline & & $(0.310)$ & & $(0.417)$ & \\
\hline \multirow[t]{2}{*}{2012 election } & -0.338 * & $-0.339 \%$ & $-0.368 *$ & $-0.363+$ & -0.205 \\
\hline & $(0.121)$ & $(0.121)$ & $(0.186)$ & $(0.186)$ & $(0.145)$ \\
\hline \multirow[t]{2}{*}{ Constant } & 6.777 和䧇 & $6.796^{* * *}$ & $6.051^{2}$ & $6.115 \%$ & 9.960 \% \\
\hline & $(0.611)$ & $(0.612)$ & $(0.871)$ & $(0.875)$ & $(0.610)$ \\
\hline Observations & 1,504 & 1,504 & 796 & 796 & 708 \\
\hline$R^{2}$ & 0.192 & 0.194 & 0.203 & 0.206 & 0.149 \\
\hline
\end{tabular}

Notes: Controls included in the model: Ran in 2008 (2010), Committee Chair, Committee Ranking Member, Party Leader, Prestige Committee, Median Income, Urban, White, Obama, Obama * Rep. Robust standard errors in parentheses.

$* * p<.01 ; * p<.05 ;+p<.1$. 
significant effect on the amount of money candidates collected in small donations. While Democratic women incumbents are predicted to collect more money in unitemized donations than their male counterparts, female Republican incumbents are predicted to raise 50\% less than a male Republican incumbent, although this is not a statistically significant difference.

Because most women who run are challengers and open seat candidates competing in primaries, it is important to analyze how their fundraising sources and overall success compare to similarly situated male candidates. Broadening the analysis to examine primary candidates provides a better measure of gender and partisan differences in the fundraising environment faced by emerging candidates who are struggling to demonstrate viability to party leaders and voters. Table 3 demonstrates that female candidates raise more money in small individual contributions than male candidates, as in the general election. To illustrate the magnitude of these differences and the impact of partisanship and gender, Figure 1 plots small individual donations raised by male and female Democratic and Republican candidates and the $95 \%$ confidence intervals for these estimates. It sets all other variables to their mean.

Clearly, the fundraising advantages held by women stem from the activities of Democratic women. Across both incumbent and nonincumbent (challenger and open seat) candidates, Democratic women raise more money from small donors than Democratic men raise. Nonincumbent Democratic women are predicted to raise $178 \%$ more than similarly situated nonincumbent Democrat males, while incumbent Democratic women are predicted to raise $89 \%$ more than their male counterparts. By contrast, being a Republican woman has a largely neutral effect on a candidate's ability to raise small donations. The overlapping confidence intervals for Republican men and women across the candidate models indicate that Republican women raise largely the same amount or slightly less in small donations than Republican men.

In contrast to the general elections, our analysis of fundraising in the primaries demonstrates that gender has a broader impact beyond small individual donations. Moreover, the fundraising experiences of women vary for Democratic and Republican women and by candidate status. Women, particularly nonincumbent Democratic women raised more money in large individual contributions (see the models in Table 4 for all candidates and the models restricted to open seat and challenger 
Table 3. Primary election unitemized donations under $\$ 200$ by candidate status and with female quality candidate

\begin{tabular}{|c|c|c|c|c|c|}
\hline Variables & All & $w /$ Fem $Q C$ & No Incum & $w /$ Fem $Q C$ & Incum \\
\hline Female & 0.883 * & $0.934^{*}$ & $1.023^{*}$ & 1.194 * * * * & 0.638 *** \\
\hline & $\begin{array}{c}(0.171) \\
0.091\end{array}$ & $\begin{array}{c}(0.182) \\
0.089\end{array}$ & $\begin{array}{c}(0.245) \\
0.328\end{array}$ & $\begin{array}{c}(0.284) \\
0.334\end{array}$ & $\begin{array}{c}(0.192) \\
-0.560\end{array}$ \\
\hline Republican & $(0.475)$ & $(0.475)$ & $(0.613)$ & $(0.614)$ & $(0.664)$ \\
\hline Female * Rep & $\begin{array}{c}-0.878 \text {; } \\
(0.273)\end{array}$ & $\begin{array}{c}-0.888^{*} \\
(0.271)\end{array}$ & $\begin{array}{c}-0.889^{*} \\
(0.333)\end{array}$ & $\begin{array}{c}-0.955^{*} \\
(0.331)\end{array}$ & $\begin{array}{r}-1.150 \% \\
(0.545)\end{array}$ \\
\hline Incumbent & $\begin{array}{l}2.648^{*} \text { * } \\
(0.147)\end{array}$ & $\begin{array}{l}2.646^{\text {* * }} \\
(0.148)\end{array}$ & & & \\
\hline Open & $\begin{array}{c}0.232 \\
(0.189)\end{array}$ & $\begin{array}{c}0.231 \\
(0.189)\end{array}$ & $\begin{array}{c}0.321 \\
(0.201)\end{array}$ & $\begin{array}{c}0.317 \\
(0.200)\end{array}$ & \\
\hline Competitive district & $\begin{array}{l}0.885^{\text {; }} \\
(0.140)\end{array}$ & $\begin{array}{l}0.884^{*} *{ }^{*} \\
(0.140)\end{array}$ & $\begin{array}{l}1.006^{\text {; }} \\
(0.169)\end{array}$ & $\begin{array}{l}1.002 \\
(0.169)\end{array}$ & $\begin{array}{l}0.643^{*} \\
(0.186)\end{array}$ \\
\hline Unopposed & $\begin{array}{l}0.636 \text { * } \\
(0.148)\end{array}$ & $\begin{array}{l}0.636 \text { " } \\
(0.148)\end{array}$ & $\begin{array}{l}0.921^{*} \\
(0.231)\end{array}$ & $\begin{array}{l}0.918 \text {; } \\
(0.230)\end{array}$ & \\
\hline One competitor & $\begin{array}{c}0.357^{*} \\
(0.144)\end{array}$ & $\begin{array}{c}0.358^{*} \\
(0.144)\end{array}$ & $\begin{array}{c}0.453^{*} \\
(0.185)\end{array}$ & $\begin{array}{c}0.452 * \\
(0.185)\end{array}$ & \\
\hline Opponent quality can & $\begin{array}{c}0.139 \\
(0.130)\end{array}$ & $\begin{array}{c}0.143 \\
(0.130)\end{array}$ & $\begin{array}{c}0.058 \\
(0.181)\end{array}$ & $\begin{array}{c}0.067 \\
(0.182)\end{array}$ & $\begin{array}{c}0.316^{*} \\
(0.123)\end{array}$ \\
\hline Nonincumbent quality can & $\begin{array}{l}1.501^{* * *} \\
(0.152)\end{array}$ & $\begin{array}{l}1.546 \text { * } \\
(0.166)\end{array}$ & $\begin{array}{l}1.454^{* * *} \\
(0.153)\end{array}$ & $\begin{array}{l}1.546^{*} \text { "* } \\
(0.171)\end{array}$ & \\
\hline Female * Quality & & $\begin{array}{r}-0.228 \\
(0.331)\end{array}$ & & $\begin{array}{c}-0.482 \\
(0.371)\end{array}$ & \\
\hline 2012 election & $\begin{array}{c}-0.033 \\
(0.119)\end{array}$ & $\begin{array}{c}-0.033 \\
(0.119)\end{array}$ & $\begin{array}{c}0.011 \\
(0.158)\end{array}$ & $\begin{array}{c}0.009 \\
(0.158)\end{array}$ & $\begin{array}{c}-0.222 \\
(0.135)\end{array}$ \\
\hline Constant & $\begin{array}{l}5.127^{* * *} \\
(0.572)\end{array}$ & $\begin{array}{l}5.121^{* * *} \\
(0.572)\end{array}$ & $\begin{array}{l}5.128^{*} \\
(0.704)\end{array}$ & $\begin{array}{l}5.100 \text { * } \\
(0.704)\end{array}$ & $\begin{array}{l}8.228 \text { "* } \\
(0.687)\end{array}$ \\
\hline Observations & 2,645 & 2,645 & 1,885 & 1,885 & 760 \\
\hline$R^{2}$ & 0.206 & 0.206 & 0.106 & 0.106 & 0.139 \\
\hline
\end{tabular}

Notes: Controls included in the model: Ran in 2008 (2010), Committee Chair, Committee Ranking Member, Party Leader, Prestige Committee, Median Income, Urban, White, Obama, Obama * Rep, Number of Days to Primary. Robust standard errors in parentheses.

$* * p<.01 ; * p<.05 ;+p<.1$. 

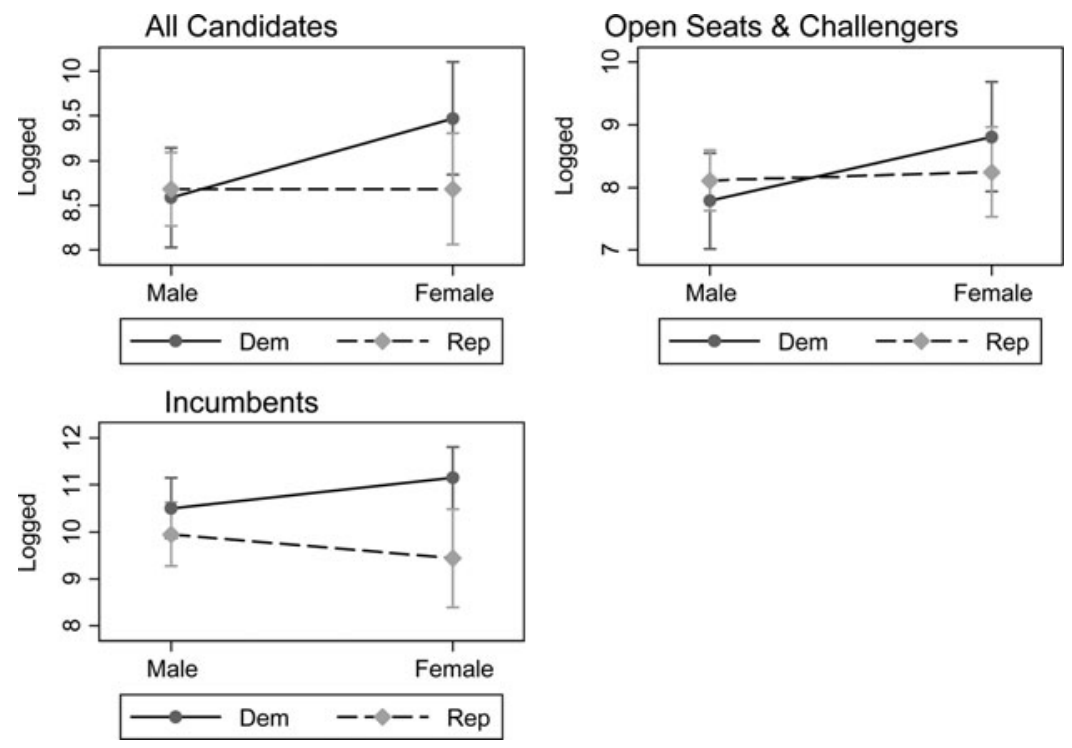

Figure 1. Primary Unitemized Contributions 2010-2012.

candidates). Figure 2 plots the predicted values with the $95 \%$ confidence intervals. Female candidates also raised more money from PACs (see Table 5). However, there are no apparent gender differences in party contributions (see Table 5).

Perhaps most importantly, Table 6 demonstrates that women, particularly the women running as challengers and in open seats, raised more money overall than their male counterparts. Thus, the coefficient for sex exerts a positive and significant impact on the total amount candidates raised for all the candidate models except for incumbents. Figure 3 demonstrates that the positive gender effects stem from the relative fundraising success of Democratic women running as challengers and open seat candidates. The predicted values for Democrats in the graphs for the all candidate and nonincumbent models indicate that Democratic women received more total contributions than similarly situated male Democrats. Female nonincumbent Democrats are predicted to raise $70 \%$ more than their male counterparts. Thus, it appears that nonincumbent Democratic women who run in primaries have greater access to the fundraising networks that support Democratic candidates. These Democratic women may be benefiting from the perception that Democratic women are 
Table 4. Primary election itemized donations $\$ 200$ or more by candidate status and with female quality candidate

\begin{tabular}{|c|c|c|c|c|c|}
\hline Variables & All & w/ Fem QC & No Incum & $w /$ Fem QC & Incum \\
\hline \multirow[t]{2}{*}{ Female } & 0.527 米 & 0.620 米 & 0.779 米的 & $1.017^{* * x}$ & 0.054 \\
\hline & $(0.144)$ & $(0.157)$ & $(0.216)$ & $(0.258)$ & $(0.084)$ \\
\hline \multirow[t]{2}{*}{ Republican } & $1.131^{\text {称 }}$ & $1.127^{*}$ & $1.442 *$ & 1.450 \% & $-0.607^{*}$ \\
\hline & $(0.409)$ & $(0.408)$ & $(0.533)$ & $(0.534)$ & $(0.265)$ \\
\hline \multirow{2}{*}{ Female * Rep } & $-0.493^{*}$ & $-0.513 *$ & -0.778 w & $-0.870 \%$ & 0.133 \\
\hline & $(0.221)$ & $(0.221)$ & $(0.299)$ & $(0.301)$ & $(0.134)$ \\
\hline Incumbent & $\begin{array}{l}3.552 \text { ** } \\
(0.118)\end{array}$ & $\begin{array}{l}3.548 \text { * } \\
(0.118)\end{array}$ & & & \\
\hline \multirow[t]{2}{*}{ Open } & $0.604^{* * *}$ & $0.601^{\text {*** }}$ & $0.623 *$ & $0.616^{* *}$ & \\
\hline & $(0.169)$ & $(0.169)$ & $(0.183)$ & $(0.182)$ & \\
\hline \multirow[t]{2}{*}{ Competitive district } & $1.138^{* * * 2 *}$ & $1.135 \%$ & $1.318^{*}$ & $1.313^{*}$ & $0.445^{* * *}$ \\
\hline & $(0.117)$ & (0.117) & $(0.149)$ & $(0.149)$ & $(0.067)$ \\
\hline \multirow[t]{2}{*}{ Opponent quality can } & $0.191+$ & $0.198+$ & 0.226 & 0.239 & 0.080 \\
\hline & $(0.109)$ & $(0.109)$ & $(0.159)$ & $(0.159)$ & $(0.057)$ \\
\hline \multirow[t]{2}{*}{ Nonincumbent quality can } & $1.994 \%$ & 2.077 ** & $1.936 \%$ & $2.064 \%$ & \\
\hline & $(0.125)$ & $(0.135)$ & $(0.127)$ & (0.138) & \\
\hline \multirow[t]{2}{*}{ Unopposed } & $0.399 \%$ & 0.399 & $0.722 *$ & $0.716^{*}$ & $0.127+$ \\
\hline & $(0.126)$ & $(0.125)$ & $(0.206)$ & $(0.206)$ & $(0.067)$ \\
\hline \multirow[t]{2}{*}{ One competitor } & 0.061 & 0.062 & 0.043 & 0.041 & 0.061 \\
\hline & $(0.129)$ & $(0.129)$ & $(0.171)$ & $(0.171)$ & $(0.076)$ \\
\hline \multirow[t]{2}{*}{ Female * Quality } & & $-0.420 \%$ & & -0.674 皮 & \\
\hline & & $(0.199)$ & & $(0.247)$ & \\
\hline \multirow[t]{2}{*}{2012 election } & 0.042 & 0.043 & 0.025 & 0.022 & $0.125^{*}$ \\
\hline & $(0.108)$ & $(0.108)$ & $(0.153)$ & $(0.153)$ & $(0.054)$ \\
\hline \multirow[t]{2}{*}{ Constant } & $6.753^{\text {棌 }}$ & $6.742 *$ & $6.576 \%$ & 6.537 米 & 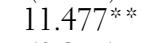 \\
\hline & $(0.497)$ & $(0.496)$ & $(0.670)$ & $(0.670)$ & $(0.277)$ \\
\hline \multirow{2}{*}{$\begin{array}{l}\text { Observations } \\
R^{2}\end{array}$} & 2,645 & 2,645 & 1,885 & 1,885 & 760 \\
\hline & 0.364 & 0.364 & 0.184 & 0.186 & 0.273 \\
\hline
\end{tabular}

Notes: Controls included in the model: Ran in 2008 (2010), Committee Chair, Committee Ranking Member, Party Leader, Prestige Committee, Median Income, Urban, White, Obama, Obama * Rep, Number of Days to Primary. Robust standard errors in parentheses. ${ }^{* *} p<.01 ;{ }^{*} p<.05 ;+p<.1$. 

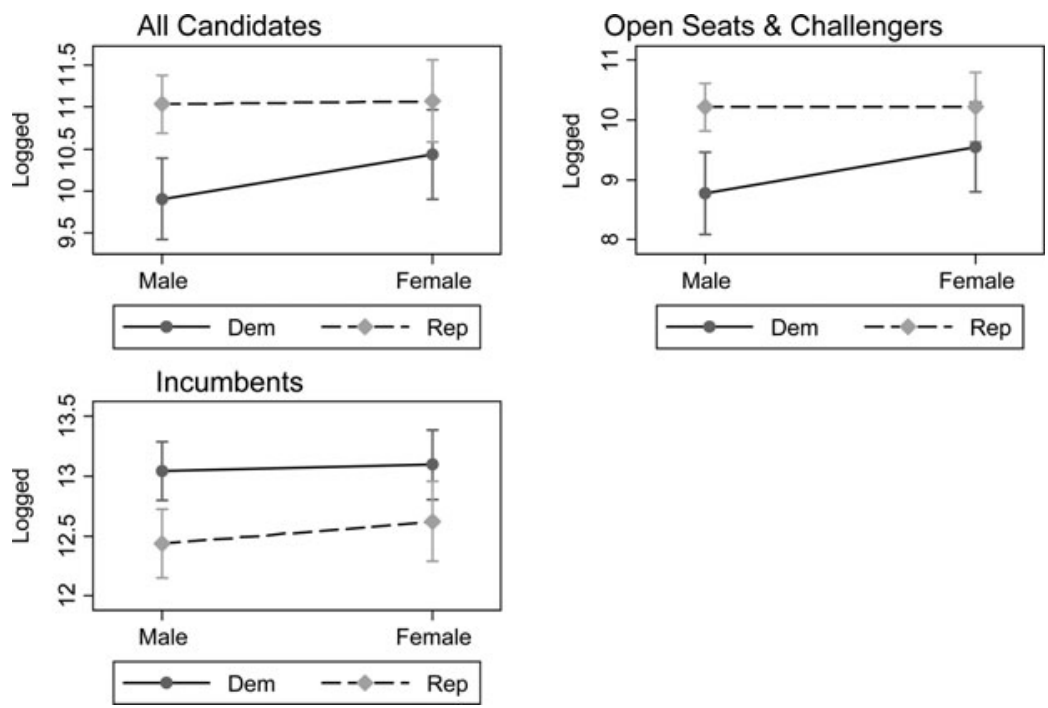

FIgURE 2. Primary Itemized Contributions 2010-2012.

more liberal (Koch 2000), and the individual donors who contribute to campaigns are more likely to be driven by ideology and attracted to liberal candidates (Barber 2016; Francia et al. 2003, 2005; Gimpel, Lee, and Pearson-Merkowitz 2008; Johnson 2010).

For Republican women, the picture is more complicated. Being a Republican woman generally did not significantly impact the amount of money a candidate collected or the sources of those contributions (with the exception discussed below of nonincumbent candidates when the interaction for female quality candidates is included in the models for large individual donations and total contributions in Tables 4 and 6). Tables 4 and 6 suggest that Republican women raised slightly less money overall and in large itemized contributions. This is particularly true for the Republican women who ran as challengers and in open seats, who also constitute the majority of female Republican candidates. Yet, taking into account both sex and Republican partisanship, the graphs of predicted money raised in Figures 2 and 3 reveal no statistically significant differences in the amount of large individual contributions male and female Republican candidates are predicted to collect or in the predicted size of their total war chests. Overall, the primary and general election fundraising trends suggest that being a woman candidate yields important fundraising advantages for Democratic 
Table 5. Primary election PAC contributions by candidate status and with female quality candidate

\begin{tabular}{|c|c|c|c|c|c|c|c|c|c|c|}
\hline Variables & $\begin{array}{c}\text { PAC } \\
\text { All }\end{array}$ & $\begin{array}{c}\text { PAC } \\
w / \text { Fem } Q C\end{array}$ & $\begin{array}{c}\text { PAC } \\
\text { No Incum }\end{array}$ & $\begin{array}{c}\text { PAC } \\
w / \text { Fem } Q C\end{array}$ & $\begin{array}{c}\text { PAC } \\
\text { Incum }\end{array}$ & $\begin{array}{c}\text { Party } \\
\text { All }\end{array}$ & $\begin{array}{c}\text { Party } \\
\text { w/ Fem } Q C\end{array}$ & $\begin{array}{c}\text { Party } \\
\text { No Incum }\end{array}$ & $\begin{array}{c}\text { Party } \\
\text { w/ Fem } Q C\end{array}$ & $\begin{array}{l}\text { Party } \\
\text { Incum }\end{array}$ \\
\hline Female & $\begin{array}{c}0.607^{\text {* }} \\
(0.243)\end{array}$ & $\begin{array}{l}0.719^{* * * *} \\
(0.258)\end{array}$ & $\begin{array}{l}0.952^{* * *} \\
(0.367)\end{array}$ & $\begin{array}{l}1.277^{\text {米虾 }} \\
(0.431)\end{array}$ & $\begin{array}{r}-0.057 \\
(0.079)\end{array}$ & $\begin{array}{c}0.098 \\
(0.205)\end{array}$ & $\begin{array}{c}0.244 \\
(0.221)\end{array}$ & $\begin{array}{l}0.293 \\
(0.257)\end{array}$ & $\begin{array}{c}0.626^{*} \\
(0.293)\end{array}$ & $\begin{array}{r}-0.058 \\
(0.325)\end{array}$ \\
\hline Republican & $\begin{array}{c}0.258 \\
(0.583)\end{array}$ & $\begin{array}{c}0.253 \\
(0.583)\end{array}$ & $\begin{array}{c}0.381 \\
(0.761)\end{array}$ & $\begin{array}{c}0.392 \\
(0.762)\end{array}$ & $\begin{array}{r}-1.303^{*} \\
(0.512)\end{array}$ & $\begin{array}{c}-2.981^{*} \\
(0.429)\end{array}$ & $\begin{array}{c}-2.987^{\text {* }} \\
(0.428)\end{array}$ & $\begin{array}{c}-1.977^{* * *} \\
(0.468)\end{array}$ & $\begin{array}{c}-1.966^{*} \\
(0.465)\end{array}$ & $\begin{array}{c}-3.330 \text {; } \\
(1.231)\end{array}$ \\
\hline Female* Rep & $\begin{array}{c}-0.321 \\
(0.363)\end{array}$ & $\begin{array}{r}-0.345 \\
(0.364)\end{array}$ & $\begin{array}{c}-0.658 \\
(0.497)\end{array}$ & $\begin{array}{c}-0.783 \\
(0.507)\end{array}$ & $\begin{array}{c}0.300^{*} \\
(0.137)\end{array}$ & $\begin{array}{c}-0.109 \\
(0.267)\end{array}$ & $\begin{array}{c}-0.140 \\
(0.267)\end{array}$ & $\begin{array}{c}-0.296 \\
(0.312)\end{array}$ & $\begin{array}{c}-0.425 \\
(0.320)\end{array}$ & $\begin{array}{c}0.011 \\
(0.613)\end{array}$ \\
\hline Incumbent & $\begin{array}{l}9.328^{\text {; }} \\
(0.183)\end{array}$ & $\begin{array}{l}9.323^{* * *} \\
(0.183)\end{array}$ & & & & $\begin{array}{l}1.842 \text { ** } \\
(0.181)\end{array}$ & $\begin{array}{l}1.836^{\text {***:* }} \\
(0.181)\end{array}$ & & & \\
\hline Open & $\begin{array}{l}1.482^{* * *} \\
(0.236)\end{array}$ & $\begin{array}{l}1.479^{* * *} \\
(0.236)\end{array}$ & $\begin{array}{l}1.630^{* * *} \\
(0.264)\end{array}$ & $\begin{array}{l}1.622^{* * *} \\
(0.263)\end{array}$ & & $\begin{array}{c}0.007 \\
(0.160)\end{array}$ & $\begin{array}{c}0.002 \\
(0.160)\end{array}$ & $\begin{array}{c}0.055 \\
(0.154)\end{array}$ & $\begin{array}{c}0.046 \\
(0.154)\end{array}$ & \\
\hline Competitive district & 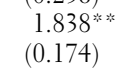 & $\begin{array}{l}1.834^{* * * *} \\
(0.174)\end{array}$ & $\begin{array}{l}2.377^{\text {**** }} \\
(0.227)\end{array}$ & $\begin{array}{l}2.371^{*} \\
(0.226)\end{array}$ & $\begin{array}{l}0.451^{* * *} \\
(0.082)\end{array}$ & 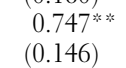 & $\begin{array}{l}0.742^{* * * *} \\
(0.146)\end{array}$ & $\begin{array}{l}0.547^{\text {***.* }} \\
(0.153)\end{array}$ & $\begin{array}{l}0.540^{* * *} \\
(0.153)\end{array}$ & $\begin{array}{l}1.763^{\text {**** }} \\
(0.379)\end{array}$ \\
\hline Unopposed & $\begin{array}{l}1.395^{*} \\
(0.186)\end{array}$ & $\begin{array}{l}1.395^{* * *} \\
(0.186)\end{array}$ & $\begin{array}{l}2.453^{* * *} \\
(0.302)\end{array}$ & $\begin{array}{l}2.446^{\text {* }} \\
(0.303)\end{array}$ & $\begin{array}{c}0.113 \\
(0.102)\end{array}$ & $\begin{array}{l}1.108^{* * *} \\
(0.186)\end{array}$ & $\begin{array}{l}1.107^{* * 2 \cdot k} \\
(0.185)\end{array}$ & $\begin{array}{l}1.593^{\text {*** }} \\
(0.250)\end{array}$ & $\begin{array}{l}1.585^{* * *} \\
(0.248)\end{array}$ & $\begin{array}{c}0.153 \\
(0.296)\end{array}$ \\
\hline One competitor & $\begin{array}{l}0.532^{*} \\
(0.175)\end{array}$ & $\begin{array}{l}0.533^{*} \text { ** } \\
(0.175)\end{array}$ & $\begin{array}{c}0.449+ \\
(0.231)\end{array}$ & $\begin{array}{c}0.447+ \\
(0.232)\end{array}$ & $\begin{array}{c}0.080 \\
(0.116)\end{array}$ & $\begin{array}{c}0.256+ \\
(0.144)\end{array}$ & $\begin{array}{c}0.258+ \\
(0.144)\end{array}$ & $\begin{array}{c}0.252 \\
(0.162)\end{array}$ & $\begin{array}{c}0.251 \\
(0.163)\end{array}$ & $\begin{array}{c}-0.120 \\
(0.319)\end{array}$ \\
\hline Opponent quality can & $\begin{array}{c}-0.037 \\
(0.168)\end{array}$ & $\begin{array}{c}-0.029 \\
(0.168)\end{array}$ & $\begin{array}{c}-0.029 \\
(0.246)\end{array}$ & $\begin{array}{c}-0.012 \\
(0.246)\end{array}$ & $\begin{array}{c}0.093 \\
(0.094)\end{array}$ & $\begin{array}{c}0.135 \\
(0.134)\end{array}$ & $\begin{array}{c}0.146 \\
(0.134)\end{array}$ & $\begin{array}{c}-0.079 \\
(0.154)\end{array}$ & $\begin{array}{c}-0.062 \\
(0.154)\end{array}$ & $\begin{array}{c}0.308 \\
(0.270)\end{array}$ \\
\hline Nonincum. quality can & $\begin{array}{l}3.939^{*} \text {; } \\
(0.236)\end{array}$ & $\begin{array}{l}4.038^{* * *} \\
(0.257)\end{array}$ & $\begin{array}{l}3.778^{* * * *} \\
(0.237)\end{array}$ & $\begin{array}{l}3.952 * * \\
(0.264)\end{array}$ & & $\begin{array}{l}0.487^{*} \text { 米 } \\
(0.150)\end{array}$ & $\begin{array}{l}0.616^{* \text { *** }} \\
(0.164)\end{array}$ & $\begin{array}{l}0.491^{\text {** }} \\
(0.150)\end{array}$ & $\begin{array}{l}0.670 \text { *** } \\
(0.164)\end{array}$ & \\
\hline Female * Quality & & $\begin{array}{c}-0.503 \\
(0.490)\end{array}$ & & $\begin{array}{r}-0.917 \\
(0.559)\end{array}$ & & & $\begin{array}{c}-0.656^{*} \\
(0.324)\end{array}$ & & $\begin{array}{c}-0.941^{*} \\
(0.359)\end{array}$ & \\
\hline 2012 election & $\begin{array}{c}0.318^{*} \\
(0.139)\end{array}$ & $\begin{array}{c}0.319^{*} \\
(0.138)\end{array}$ & $\begin{array}{c}0.309 \\
(0.200)\end{array}$ & $\begin{array}{c}0.305 \\
(0.200)\end{array}$ & $\begin{array}{c}0.164^{*} \\
(0.081)\end{array}$ & $\begin{array}{r}-0.250 * \\
(0.118)\end{array}$ & $\begin{array}{r}-0.250^{*} \\
(0.118)\end{array}$ & $\begin{array}{c}-0.071 \\
(0.133)\end{array}$ & $\begin{array}{c}-0.076 \\
(0.133)\end{array}$ & $\begin{array}{c}-0.772^{* * * *} \\
(0.240)\end{array}$ \\
\hline Constant & $\begin{array}{r}-0.314 \\
(0.665)\end{array}$ & $\begin{array}{r}-0.327 \\
(0.664)\end{array}$ & $\begin{array}{c}-1.367 \\
(0.939)\end{array}$ & $\begin{array}{r}-1.419 \\
(0.939)\end{array}$ & $\begin{array}{l}12.543^{* * * *} \\
(0.264)\end{array}$ & $\begin{array}{l}1.258^{*} \\
(0.546)\end{array}$ & $\begin{array}{l}1.240 * \\
(0.544)\end{array}$ & $\begin{array}{l}1.599 * * \\
(0.584)\end{array}$ & $\begin{array}{l}1.545^{* * *} \\
(0.580)\end{array}$ & $\begin{array}{c}1.518 \\
(1.230)\end{array}$ \\
\hline Observations & 2,645 & 2,645 & 1,885 & 1,885 & 760 & 2,645 & 2,645 & 1,885 & 1,885 & 760 \\
\hline$R^{2}$ & 0.633 & 0.633 & 0.292 & 0.293 & 0.121 & 0.207 & 0.208 & 0.131 & 0.135 & 0.191 \\
\hline
\end{tabular}

Notes: Controls included in the model: Ran in 2008 (2010), Committee Chair, Committee Ranking Member, Party Leader, Prestige Committee, Median Income, Urban, White, Obama, Obama * Rep, Number of Days to Primary. Robust standard errors in parentheses. * $p<.01$; * $p<.05 ;+p<.1$. 
Table 6. Primary election total contributions by candidate status and with female quality candidate

\begin{tabular}{|c|c|c|c|c|c|}
\hline Variables & All & w/ Fem QC & No Incum & $w /$ Fem QC & Incum \\
\hline Female & $\begin{array}{l}0.347^{\text {***; }} \\
(0.098)\end{array}$ & $\begin{array}{l}0.423^{* * *} \\
(0.104)\end{array}$ & $\begin{array}{l}0.531^{* *} \\
(0.146)\end{array}$ & $\begin{array}{l}0.718^{\text {*** }} \\
(0.168)\end{array}$ & $\begin{array}{c}0.023 \\
(0.058)\end{array}$ \\
\hline Republican & $\begin{array}{l}0.733^{* * *} \\
(0.281)\end{array}$ & $\begin{array}{l}0.730^{* * * *} \\
(0.282)\end{array}$ & $\begin{array}{l}0.978^{*} \\
(0.376)\end{array}$ & $\begin{array}{l}0.985^{* * *} \\
(0.377)\end{array}$ & $\begin{array}{c}-0.713^{\text {*: }}(0.194) \\
\end{array}$ \\
\hline Female ${ }^{*}$ Rep & $\begin{array}{c}-0.368^{*} \\
(0.147)\end{array}$ & $\begin{array}{c}-0.384^{* * *} \\
(0.146)\end{array}$ & $\begin{array}{c}-0.584^{* * *} \\
(0.197)\end{array}$ & $\begin{array}{c}-0.656^{* * *} \\
(0.198)\end{array}$ & $\begin{array}{c}0.094 \\
(0.098)\end{array}$ \\
\hline Incumbent & $\begin{array}{l}3.371^{* * *} \\
(0.081)\end{array}$ & $\begin{array}{l}3.368^{* * * *} \\
(0.081)\end{array}$ & & & \\
\hline Open & $\begin{array}{l}0.527^{* * *} \\
(0.119)\end{array}$ & $\begin{array}{l}0.525^{* * *} \\
(0.119)\end{array}$ & $\begin{array}{l}0.553^{* * *} \\
(0.131)\end{array}$ & $\begin{array}{l}0.548^{* * *} \\
(0.131)\end{array}$ & \\
\hline Competitive district & $\begin{array}{l}0.968^{* * *} \\
(0.084)\end{array}$ & $\begin{array}{l}0.966^{*} \\
(0.084)\end{array}$ & $\begin{array}{l}1.123^{* * *} \\
(0.104)\end{array}$ & $\begin{array}{l}1.119 * * \\
(0.104)\end{array}$ & $\begin{array}{l}0.387^{\text {***⿲丶丶㇒木 }} \\
(0.054)\end{array}$ \\
\hline Unopposed & $\begin{array}{l}0.377^{* * * *} \\
(0.084)\end{array}$ & $\begin{array}{l}0.377 \text { ** } \\
(0.084)\end{array}$ & $\begin{array}{l}0.656^{* * *} \\
(0.136)\end{array}$ & $\begin{array}{l}0.652^{* * *} \\
(0.136)\end{array}$ & \\
\hline One competitor & $\begin{array}{c}0.126 \\
(0.085)\end{array}$ & $\begin{array}{c}0.127 \\
(0.085)\end{array}$ & $\begin{array}{c}0.103 \\
(0.112)\end{array}$ & $\begin{array}{c}0.102 \\
(0.112)\end{array}$ & \\
\hline Opponent quality can & $\begin{array}{c}0.156^{*} \\
(0.075)\end{array}$ & $\begin{array}{l}0.161^{*} \\
(0.076)\end{array}$ & $\begin{array}{c}0.169 \\
(0.110)\end{array}$ & $\begin{array}{c}0.179 \\
(0.111)\end{array}$ & $\begin{array}{l}0.113^{* * * *} \\
(0.042)\end{array}$ \\
\hline Nonincumbent quality can & $\begin{array}{l}1.500^{* * *} \\
(0.086)\end{array}$ & $\begin{array}{l}1.566^{* * *} \\
(0.093)\end{array}$ & $\begin{array}{l}1.449 * * \\
(0.087)\end{array}$ & $\begin{array}{l}1.550^{* * *} \\
(0.095)\end{array}$ & \\
\hline Female * Quality & & $\begin{array}{c}-0.339 * \\
(0.156)\end{array}$ & & $\begin{array}{c}-0.528^{* * *} \\
(0.180)\end{array}$ & \\
\hline 2012 election & $\begin{array}{c}0.059 \\
(0.073)\end{array}$ & $\begin{array}{c}0.060 \\
(0.073)\end{array}$ & $\begin{array}{c}0.042 \\
(0.103)\end{array}$ & $\begin{array}{c}0.039 \\
(0.103)\end{array}$ & $\begin{array}{l}0.116^{\text {*** }} \\
(0.038)\end{array}$ \\
\hline Constant & $\begin{array}{l}8.033^{* * *} \\
(0.352)\end{array}$ & $\begin{array}{l}8.024 \\
(0.351)\end{array}$ & $\begin{array}{l}7.770 \text { * } \\
(0.468)\end{array}$ & $\begin{array}{l}7.740^{*} \text {. } \\
(0.468)\end{array}$ & $\begin{array}{l}12.656^{* * * * x^{4}} \\
(0.205)\end{array}$ \\
\hline Observations & 2,645 & 2,645 & 1,885 & 1,885 & 760 \\
\hline$R^{2}$ & 0.549 & 0.549 & 0.268 & 0.270 & 0.352 \\
\hline
\end{tabular}

Notes: Controls included in the model: Ran in 2008 (2010), Committee Chair, Committee Ranking Member, Party Leader, Prestige Committee, Median Income, Urban, White, Obama, Obama * Rep, Number of Days to Primary. Robust standard errors in parentheses. ** $p<.01$; * $p<.05 ;+p<.1$. 
women but has a neutral or slightly negative impact on fundraising for Republican women.

Yet the fundraising advantages held by Democratic women do not translate into additional advantages at the ballot box. Regression models analyzing primary and general election outcomes and vote share (results not shown) indicate no independent effect of sex or the amount of money raised by the female candidate once we account for the traditional factors that predict electoral victory such as overall level of fundraising, race competitiveness, partisanship of the district, and the quality of the candidates. ${ }^{9}$ Thus, it is likely that the impact of gender differences in fundraising activity is more important at the candidate emergence stage than for electoral outcomes. The belief that he or she can put together a donor network and raise the necessary funds to win will be crucial to a candidate's decision. The political ambition literature tells us that women are less likely to view themselves as qualified to run for office, and they are more likely to express concerns about fundraising (Fox and Lawless 2011; Fulton et al. 2006; Jenkins 2007). Thus, more Democratic women than Republican women may run because the Democratic women see more potential avenues for fundraising, which helps them overcome this ambition deficit.

Quality candidates are particularly likely to consider their fundraising prospects when deciding whether to run. Given recent research that indicates that women need to be higher-quality candidates to achieve the same outcomes as men, we include an interaction term between sex and nonincumbent quality candidate to evaluate whether female quality candidates raise the same amount of money as male quality candidates. For those cases in which the variable is significant, the impact is always negative. Thus, the models on nonincumbent candidates in Table 6 indicate that quality female candidates raised less money in total contributions than male quality candidates. These female quality candidates also raised fewer large individual donations and received less money from party committees than male quality candidates (see Tables 4 and 6).

9. We ran regression models on electoral outcome and vote share in the primary and general election by party and with all candidates combined. Independent variables capturing the impact of gender included candidate sex and interaction terms for gender and candidate fundraising and gender and candidate quality. None of these variables was significant once we accounted for total contributions, seat status, race competitiveness, candidate quality, quality of the opposition, number of candidates in the primary, and district characteristics. 

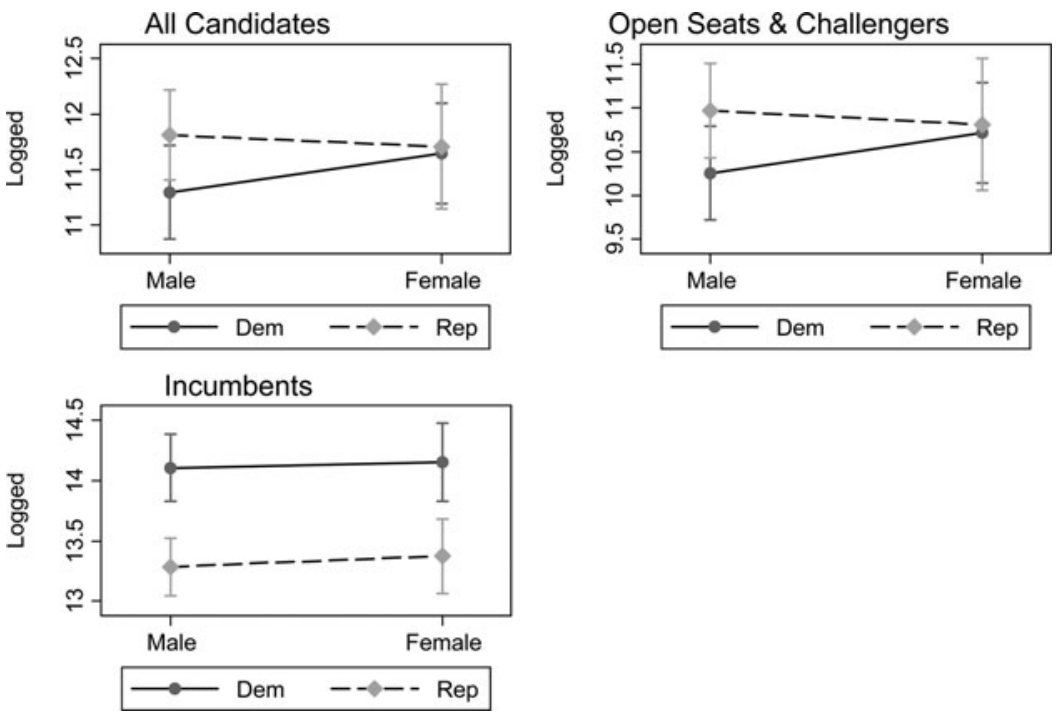

FIgure 3. Primary Total Contributions 2010-2012.

Figure 4 plots how candidate quality affects the overall fundraising success of male and female Democratic and Republican nonincumbent candidates. The problems confronted by quality female candidates likely reflect the fundraising experiences of Republican women. Female Democratic quality candidates raise just as much money as male Democratic quality nonincumbents. Moreover, nonquality Democratic

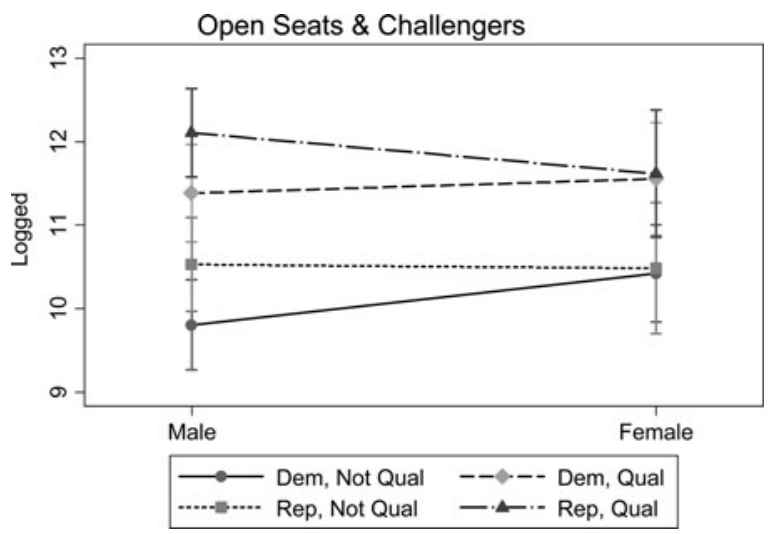

Figure 4. Primary Total Contributions 2010-2012. 
women who have never run for office are predicted to raise more money than their male counterparts. However, female quality Republican candidates are predicted to raise less money than quality Republican male candidates $(p=.089)$. It appears that Republican female quality candidates are not as well integrated into party donor networks as male Republican quality candidates, suggesting that the most electable Republican women are disadvantaged in the money race.

\section{CONCLUSION}

By focusing solely on the fundraising activities of general election candidates, previous research misses important gender and partisan differences in candidate fundraising. Our examination of primary elections demonstrates that both gender and partisanship matter when candidates are competing to demonstrate viability to fellow partisans and build a donor network that will help them secure their party's nomination. During the primary process, we find distinct differences in the sources and overall fundraising success of male and female Democratic and Republican candidates.

Among Democrats, women raise more money than their male counterparts in small and large individual donations, and they raise more total contributions than similarly situated men. These differences are strongest among the open seat and challenger candidates who cannot rely on the power of incumbency to secure the nomination. These candidates must acquire enough money to convey their vision of Democratic politics to primary voters in a setting where partisan cues are constant and a candidate's demographic profile and personal story become more central to the voter/donor decision. Because nonincumbent House candidates raise the majority of their funds from individual donors who are motivated by ideological agreement with the candidate (Francia et al. 2003, 2005; Barber 2016), the assumption that women candidates are more liberal likely boosts the candidacies of Democratic women. Moreover, the increasing importance of women's organizations and civil rights groups to the base of the party (Burrell 2014; Sanbonmatsu 2002) has elevated the importance of diversity for activists and donors making Democratic donors more receptive to calls to elect women. Thus, it appears that nonincumbent Democratic women who are considering a candidacy may be more likely to see a path to developing the necessary fundraising network to mount a campaign and this may contribute to the 
trend of more Democratic than Republican women running for office. Indeed, examining individual donors, Crespin and Dietz (2010) find that Democratic women exhibit a distinctive fundraising pattern, collecting more of their individual contributions from small unitemized donations, and they speculate that donor networks, particularly EMILY's List, which bundles individual contributions for pro-choice Democratic women, are helping drive this difference.

The fact that Democratic women's greater fundraising prowess does not translate into more primary wins or higher vote shares is harder to explain. The political ambition literature suggests that women need to feel more qualified than men before they throw their hat into the ring (Fox and Lawless 2011). Thus, it is possible that female Democratic women candidates require an even friendlier fundraising path before they will commit to a candidacy. On the other hand, it is also possible that Democratic women need to work harder to achieve the same results. Analyzing general election results from 1984 to 2012, Pearson and McGhee (2013) find that nonincumbent Democratic but not Republican women need to raise more money and run in more partisan friendly districts to win suggesting that Democratic women need to work harder to win at the same rate.

While current fundraising trends may benefit aspiring Democratic women candidates, the potential fundraising landscape for Republican women may be narrower. In contrast to female Democratic primary candidates, for Republican women, the impact of gender on fundraising was largely neutral and sometimes negative. Thus, Republican women who do run generally raise similar amounts of money and win at the same rate as men. However, there are very few Republican women running. When we account for candidate quality, we find that among Democrats, the quality female candidates raise as much money as the quality male candidates, and the female Democratic candidates with less political experience actually out-raise their male counterparts. By contrast, among Republicans, the inexperienced female candidates attract just as little fundraising support as the less experienced male Republican candidates. However, the quality Republican female candidates raise less money on average than the male quality candidates, suggesting that the most viable female Republican candidates have more difficulty accessing Republican donor networks than similarly situated men. By definition, the quality female candidates have run for office before and have had to build a donor network to win an election. However, congressional elections represent more coveted positions with increased competition. As Congress becomes more polarized, these local congressional races are 
increasingly nationalized. The assumption that women are more moderate (King and Matland 2003) may hurt the efforts of viable conservative women to attract an ideologically motivated national Republican donor base, even if they have previously been successful at the local or state level.

Looking to the future, the majority of Republican women running for office will be nonincumbents. Therefore, the ability of quality female challengers and open seat candidates to build donor networks will be of paramount importance to increasing the number of Republican women in office. The Republican Party has only recently focused more attention on recruitment of female candidates, and allied party groups looking to elect more conservative women such as Maggie's List and the Susan B. Anthony List have not developed their female donor networks to the level of Democratic-aligned groups like EMILY's List (Burrell 2014; Cooperman 2013; Elder 2014). Our research suggests that the Republican Party needs to put more resources into recruiting and developing donor networks for quality female candidates.

\section{SUPPLEMENTARY MATERIAL}

To view supplementary material for this article, please visit http://dx.doi. org/10.1017/S1743923X1600009X

Karin E. Kitchens is a Ph.D. candidate in the Department of Government at Georgetown University, Washington, D.C.: karinkitchens@gmail.com; Michele L. Swers is Professor of Political Science at Georgetown University, Washington, D.C.: mls47@georgetown.edu.

\section{REFERENCES}

Abramowitz, Alan I. 2010. The Disappearing Center: Engaged Citizens, Polarization, and American Democracy. New Haven, CT: Yale University Press.

Barber, Michael. 2016. "Donation Motivations: Testing Theories of Access and Ideology." Political Research Quarterly 69 (1): 148-59.

Bawn, Kathleen, Martin Cohen, David Karol, Seth Masket, Hans Noel and John Zaller. 2012. "A Theory of Political Parties: Groups, Policy Demands, and Nominations in American Politics." Perspectives on Politics 10 (3): 571-97.

Boatright, Robert G. 2013. Getting Primaried: The Changing Politics of Congressional Primary Challenges. Ann Arbor: University of Michigan Press.

Burns, Nancy, Kay Lehman Schlozman, and Sidney Verba. 2001. The Private Roots of Public Action: Gender, Equality, and Political Participation. Cambridge, MA: Harvard University Press. 
Burrell, Barbara. 1994. A Woman's Place Is in the House: Campaigning for Congress in the Feminist Era. Ann Arbor: University of Michigan Press.

_ 2008. "Political Parties, Fund-Raising, and Sex." In Legislative Women: Getting Elected, Getting Ahead, ed. Beth Reingold. Boulder, CO: Lynne Rienner, 41-58.

. 2010. "Political Parties and Women's Organizations: Bringing Women into the Electoral Arena." In Gender and Elections: Shaping the Future of American Politics, 2nd ed., eds. Susan J. Carroll and Richard L. Fox. New York: Cambridge University Press, 210-38.

- 2014. Gender in Campaigns for the U.S. House of Representatives. Ann Arbor: University of Michigan Press.

Center for American Women and Politics. 2015. "Women in U.S. Congress 2015.” http:// www.cawp.rutgers.edu/women-us-congress-2015 (accessed March 15, 2016).

Cooperman, Rosalyn. 2013. "The Elephant in the Room: Conservative Women's PACs and Republican Women Candidates in U.S. House Elections, 2008-2012.” Prepared for the European Consortium for Political Research General Conference, Sciences Po Bordeaux, Domaine Universitaire, France.

Crespin, Michael H., and Janna L. Dietz. 2010. “If You Can't Join'Em, Beat'Em: The Gender Gap in Individual Donations to Congressional Candidates." Political Research Quarterly 63 (3): 581-93.

Dabelko, Kristen La Cour, and Paul S. Herrnson. 1997. “Women's and Men’s Campaigns for the U.S. House of Representatives.” Political Research Quarterly 50 (1): 121 -35.

Elder, Laurel. 2008. "Whither Republican Women: The Growing Partisan Gap Among Women in Congress." The Forum 6 (1): article 13.

- 2012. "The Partisan Gap among Women State Legislators." Journal of Women, Politics \& Policy 33 (1): 65-85.

- 2014. "Women and the Parties: An Analysis of Republican and Democratic Strategists for Recruiting Women Candidates.” Presented at the American Political Science Association Conference, Washington, DC.

Fiber, Pamela, and Richard L. Fox. 2005. "A Tougher Road for Women? Assessing the Role of Gender in Congressional Elections." In Gender and American Politics: Women, Men, and the Political Process, 2nd ed., eds. Sue Tolleson-Rinehart and Jyl J. Josephson. Armonk, NY: M.E. Sharpe, 64-81.

Fox, Richard L., and Jennifer L. Lawless. 2011. "Gendered Perceptions and Political Candidacies: A Central Barrier to Women's Equality in Electoral Politics." American Journal of Political Science 55 (1): 59-73.

Francia, Peter L. 2001. "Early Fundraising by Nonincumbent Female Congressional Candidates." Women \& Politics 23 (1/2): 7-20.

Francia, Peter L., John C. Green, Paul S. Herrnson, Lynda W. Powell, and Clyde Wilcox. 2003. The Financiers of Congressional Elections: Investors, Ideologues, and Intimates. New York: Columbia University Press.

- 2005. "Limousine Liberals and Corporate Conservatives: The Financial Constituencies of the Democratic and Republican Parties." Social Science Quarterly 86 (4): $761-78$.

Frederick, Brian. 2009. "Are Women Still More Liberal in a Polarized Era? The Conditional Nature of the Relationship Between Descriptive and Substantive Representation." Congress \& the Presidency 36 (2): 181-202.

Fulton, Sarah A. 2012. "Running Backwards and in High Heels: The Gendered Quality Gap and Incumbent Electoral Success." Political Research Quarterly 65 (2): 303-14.

Fulton, Sarah A., Cherie D. Maestas, L. Sandy Maisel, and Walter J. Stone. 2006. "The Sense of a Woman: Gender and Congressional Ambition." Political Research Quarterly 59 (2): 235-48. 
Gimpel, James G., Frances E. Lee, and Joshua Kaminski. 2006. “The Political Geography of Campaign Contributions." Journal of Politics 68 (3): 626-39.

Gimpel, James G., Frances E. Lee, and Shanna Pearson-Merkowitz. 2008. “The Check Is in the Mail: Interdistrict Funding Flows in Congressional Elections." American Journal of Political Science 52 (2): 373-94.

Green, Joanne Connor. 1998. "The Role of Gender in Open-Seat Elections for the U.S. House of Representatives." Women \& Politics 19 (2): 33-55.

— . 2003. "The Times. . Are They A-Changing? An Examination of the Impact of the Value of Campaign Resources for Women and Men Candidates for the U.S. House of Representatives." Women \& Politics 25 (4): 1-29.

Herrick, Rebekah. 1996. "Is There a Gender Gap in the Value of Campaign Resources?" American Politics Quarterly 24 (1): 68-80.

Herrnson, Paul S. 2012. Congressional Elections: Campaigning at Home and in Washington. 6th ed. Washington, DC: CQ Press.

Hogan, Robert E. 2007. “The Effects of Candidate Gender on Campaign Spending in State Legislative Elections." Social Science Quarterly 88 (5): 1092-1105.

Jacobson, Gary C. 2013a. "Partisanship, Money, and Competition: Elections and the Transformation of Congress since the 1970s." In Congress Reconsidered, 10th ed., eds. Lawrence C. Dodd and Bruce I. Oppenheimer Washington, DC: CQ Press, 117-44.

. 2013b. The Politics of Congressional Elections. 8th ed. Boston: Pearson.

Jenkins, Shannon. 2007. "A Woman's Work Is Never Done? Fundraising Perception and Effort among Female State Legislative Candidates." Political Research Quarterly 60 (2): $230-39$.

Johnson, Bertram. 2010. "Individual Contributions: A Fundraising Advantage for the Ideologically Extreme?” American Politics Research 38 (5): 890-908.

King, David C., and Richard E. Matland. 2003. "Sex and the Grand Old Party: An Experimental Investigation of the Effect of Candidate Sex on Support for a Republican Candidate." American Politics Research 31 (6): 595-612.

Koch, Jeffrey W. 2000. "Do Citizens Apply Gender Stereotypes to Infer Candidates' Ideological Orientations?" Journal of Politics 62 (2): 414-29.

La Raja, Raymond J. 2013. "Richer Parties, Better Politics? Party-Centered Campaign Finance Laws and American Democracy.” The Forum 11 (4): 313-38.

Lawless, Jennifer L., and Kathryn Pearson. 2008. "The Primary Reason for Women's Underrepresentation? Re-Evaluating Conventional Wisdom." Journal of Politics 70 (1): $67-82$.

Palmer, Barbara and Dennis Simon. 2012. Women and Congressional Elections: A Century of Change. Boulder, CO: Lynne Rienner.

Pearson, Kathryn. 2013. "Congresswomen's Pursuit of Power in a Partisan Environment." In Congress Reconsidered, 10th ed., eds. Lawrence C. Dodd and Bruce I. Oppenheimer. Washington, DC: CQ Press, 59-89.

Pearson, Kathryn, and Eric McGhee. 2013. "What It Takes to Win: Questioning "Gender Neutral' Outcomes in U.S. House Elections.” Politics E Gender 9 (4): 439-62.

Sanbonmatsu, Kira. 2002. Gender Equality, Political Parties, and the Politics of Women's Place. Ann Arbor: University of Michigan Press.

- 2006. Where Women Run: Gender and Party in the American States. Ann Arbor: University of Michigan Press.

Thomsen, Danielle M. 2015. "Why So Few (Republican) Women? Explaining the Partisan Imbalance of Women in the U.S. Congress." Legislative Studies Quarterly 40 (2): 295-323.

Wolbrecht, Christina. 2000. The Politics of Women's Rights: Parties, Positions, and Change. Princeton, NJ: Princeton University Press. 